УДК 330

Волкова Н.І., к.е.н., доцент

Volkova N. Candidate of Economic Sciences, Associate Professor http://orcid.org/0000-0003-0769-3172

Задорожнюк Н.О., к.е.н., доцент

Zadorozhniuk N. Candidate of Economic Sciences, Associate Professor http://orcid.org/ 0000-0001-9708-7242

\title{
ЕКОНОМІЧНІ СТУДІЇ - МЕЙНСТРІМ СУЧАСНОЇ ЕКОНОМІЧНОЇ ТЕОРІЇ ТА ПРАКТИКИ ГОСПОДАРЮВАННЯ
}

Одеський національний політехнічний університет

В статті розкрито сутність поняття «економічні студії» в контексті сучасної економічної теорії та практики господарювання. У широкому розумінні економічні дослідження - це поліконцептуальна система знань, розвиток якої пов'язаний з постійним виникненням, обгрунтуванням, розширенням впливу одних теорій, спростуванням інших та їх протистоянням. У більш вузькому розумінні економічні студії це сукупність економічних, політичних, інформаційних та комунікаційних процесів та напрямків, що відбуваються на регіональному, національному та глобальному рівнях.

Визначено місце економічних студій у сучасних наукових дослідженнях: економічному, політичному, інформаційному та комунікаційному напрямах. Запропоновано певну структуру економічних досліджень відповідно до сучасних наукових досліджень та актуальних проблем людства. Економічні студії як дисципліна складається 3 двох складових: наукових засад становлення та розвитку науки та дисципліни «Економічні студії», тобто вивчення фундаментальних змін; теоретичні основи становлення та розвитку економічних досліджень. Питання, які мають бути вирішені у повсякденному та економічному житті, потребують їх швидкого вирішення за допомогою постійного механізму.

Основними компонентами економічних студій як навчальної дисципліни вважаються: інформаційне втручання - це сукупність цілеспрямованих заходів, що забезпечують канали розповсюдження та телекомунікації інформації про масові тенденції у заздалегідь визначеному режимі; розумна спеціалізація, що передбачає стимулювання інноваційної діяльності та впровадження інновацій, активізацію довгострокових структурних змін в економіці регіону 3 довгостроковою орієнтацією; регіональні студії - це складна категорія, яка має відношення до досліджень та моніторингу процесів, що відбуваються в регіоні. Регіональні студії можуть створити передумови для формування транснаціональних економічних та культурних зв'язків, що підтверджує тісний зв'язок між регіональними та економічними студіями.

Міжнародні економічні організації також відіграють важливу роль - як всесвітню платформу для економічних студій.

Ключові слова: економічні та регіональні студї, економічна теорія, розумна спеціалізація, інформаційні інтервенції, суспільні комунікації.

\section{ECONOMIC STUDIES - A MAINSTREAM OF MODERN ECONOMIC THEORY AND ECONOMIC PRACTICE}

\author{
Odessa National Polytechnic University
}

The article describes the essence of the concept of "economic studies" in the context of modern economic theory and practice of management. In the broad sense, economic studies are a polyconceptual system of knowledge, the development of which is connected with the constant emergence, justification, expansion of influence of some theories, refutation of others and their confrontation. In a more narrow sense, economic studies are a set of economic, political, information and communication processes and activities that take place at regional, national and global levels.

The place of economic studies in modern scientific researches is defined: economic, political, information and communication directions. A certain structure of economic studies in accordance with modern scientific researches and actual problems of humanity is offered. Economics as a discipline consists of two components: scientific principles of formation and development of science and discipline "Economic Studies", ie the study of fundamental changes; theoretical foundations of formation and development of economic studies. Issues that must be resolved in everyday economic life, necessitate their prompt decision with the help of a permanent mechanism. 
The key components of economics studies as a discipline are considered: information Intervention is a set of purposeful measures that provide channels of distribution and telecommunication of mass trend information in a predetermined mode; smart specialization envisages stimulation of innovative activity and introduction of innovations, activation of long-term structural changes in the economy of the region with a long-term orientation; regional studios - it is a complex category that is relevant to the research and monitoring of the processes taking place in the region. Regional studios can create the preconditions for forming transnational economic and cultural ties, which confirms the close link between regional and economic studios.

International economic organizations also play an important role - as a worldwide platform for economic studies.

Key words: economic and regional studies, economic theory, reasonable specialization, information interventions, public communications.

Постановка проблеми у загальному вигляді і їі з важливими науковими та практичними завданнями. Актуальність дослідження обумовлена трансформаційними процесами, що відбуваються у вищих навчальних закладах та появою нових наукових дисциплін сучасного освітнього процесу, серед яких особливе місце займають «економічні студії». Проте зміст поняття «економічні студії», його складові та місце у сучасних наукових напрямах є невирішеними питаннями. Тому безумовно важливим на сьогодні є здійснення нових та аналіз проведених наукових досліджень в межах економіки як галузі знань з метою пошуку відповідей на означені питання.

Аналіз останніх досліджень, у яких започатковано вирішення проблеми. Питання, пов'язані 3 дослідженням економічних студій $\epsilon$ відкритими, тому інноваційність цього поняття відкриває нові можливості для наукових праць. Разом з цим можна відзначити роботи, у яких розглядаються базові економічні явища та процеси [1], а також інноваційні аспекти, що відбуваються в умовах ринкової трансформації [2]. Наукові положення цих праць доцільно відобразити в економічних студіях. Також слід зазначити регіональні студії [3], які мають схожість щодо логіки розкриття змісту економічних студій. Проаналізовані дослідження підтверджують відсутність чіткого наукового бачення змісту та структури економічних студій як нового напряму в науці та освітньому процесі.

Цілі статті. Ключовими цілями статті є:

- з'ясування сутності економічних студій як нового наукового напряму;

- визначення місця економічних студій у сучасних наукових дослідженнях;

- побудова структури економічних студій у контексті сучасної економічної теорії та практики господарювання.

Виклад основного матеріалу дослідження 3 повним обгрунтуванням отриманих наукових досліджень. Початок XXI ст. характеризується такими тенденціями:

- зближення країн і народів;

- поєднанням економічного та інформаційного простору;

- стрімким розвитком різноманітних технологій;

- збільшенням ролі нових знань та комунікаційної складової у практиці господарювання.

Все це знаходить своє відображення у трансформаційних процесах, які відбуваються в науковому та освітньому процесах - з'являються нові терміни, наукові напрями та навчальні дисципліни. У зв'язку з вищезазначеним виникає науковий i практичний інтерес щодо розкриття сутності та дослідження нових термінів, серед яких особливе місце займають «економічні студії».

Економічні студії - це мейнстрім економічної теорії та практики господарювання в сучасних умовах. У широкому розумінні економічні студії - це поліконцептуальна система знань, розвиток якої пов'язаний з постійним виникненням, обгрунтуванням, розширенням впливу одних теорій, спростуванням інших та їх протиборством [4]. У 
більш вузькому розумінні економічні студії - це комплекс економічних, політичних та інформаційно-комунікативних процесів та заходів, що відбуваються на регіональному, національному та світовому рівні.

Предметом дослідження економічних студії виступає система знань з різних наукових напрямів про сучасну економіку. Тобто можна стверджувати, що економічні студії тісно взаємодіють з багатьма навчальними дисциплінами: економічною теорією, міжнародними економічними відносинами, суспільними та маркетинговими комунікаціями, а також деякими політичними та інформаційними напрямами наукових досліджень тощо. Особливу увагу слід приділити інформаційній інтервенції та політиці розумної спеціалізації, які на сьогодні $є$ одними з найактуальніших питань як у науці, так й у практичній діяльності.

Інформаційна інтервенція - це комплекс цілеспрямованих заходів, що забезпечують подання каналами розповсюдження та телекомунікацій масової тенденційної інформації у заздалегідь заданому режимі або ㄲï інтерпретацію у потрібному ракурсі з метою впливу на суспільну думку і прийняття рішень в іншій державі, а також інформаційні технології і інформаційна техніка та обладнання іноземного виробництва, споживачами якої є мешканці країни-об'єкта інформаційної інтервенції [5].

Смарт-спеціалізація передбачає стимулювання інноваційної діяльності та впровадження інновацій, активізацію довгострокових структурних змін в економіці регіону з орієнтацією на перспективу, тобто формування такої політики, яка дасть змогу регіону зайняти важливі ніші на глобальних ринках [6].

Місце економічних студій у сучасних наукових дослідженнях наведено на рис.1.

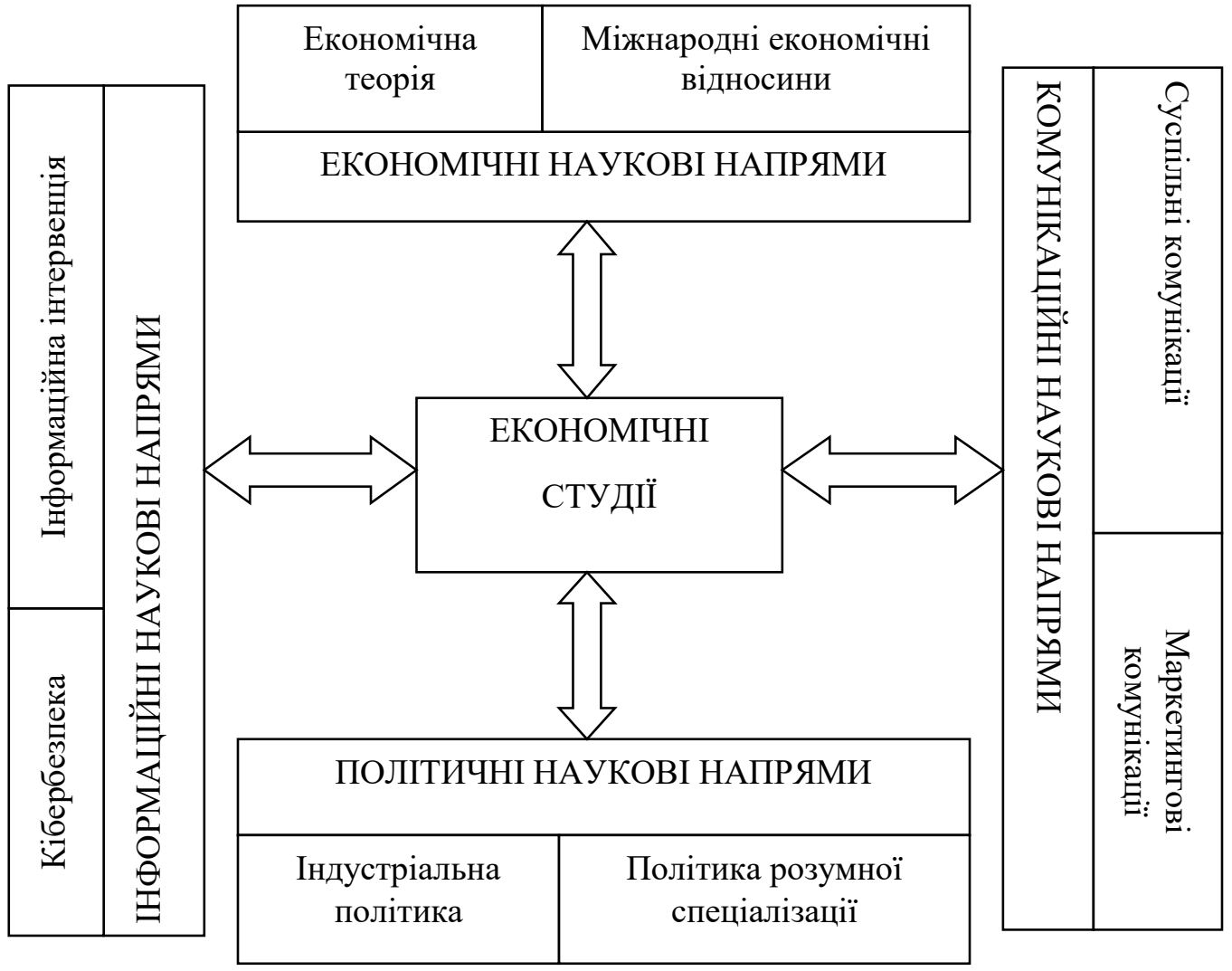

Рис. 1 Місце економічних студій у сучасних наукових дослідженнях Джерело: розроблено авторами 
Отже, економічні студії, поєднуючи актуальні та різні напрями науки, займають важливе місце як у науковому просторі, так й у сучасному освітньому процесі.

Для більш повного розуміння змісту економічних студій слід визначити їх структуру, авторське бачення якої представлено на рис. 2.

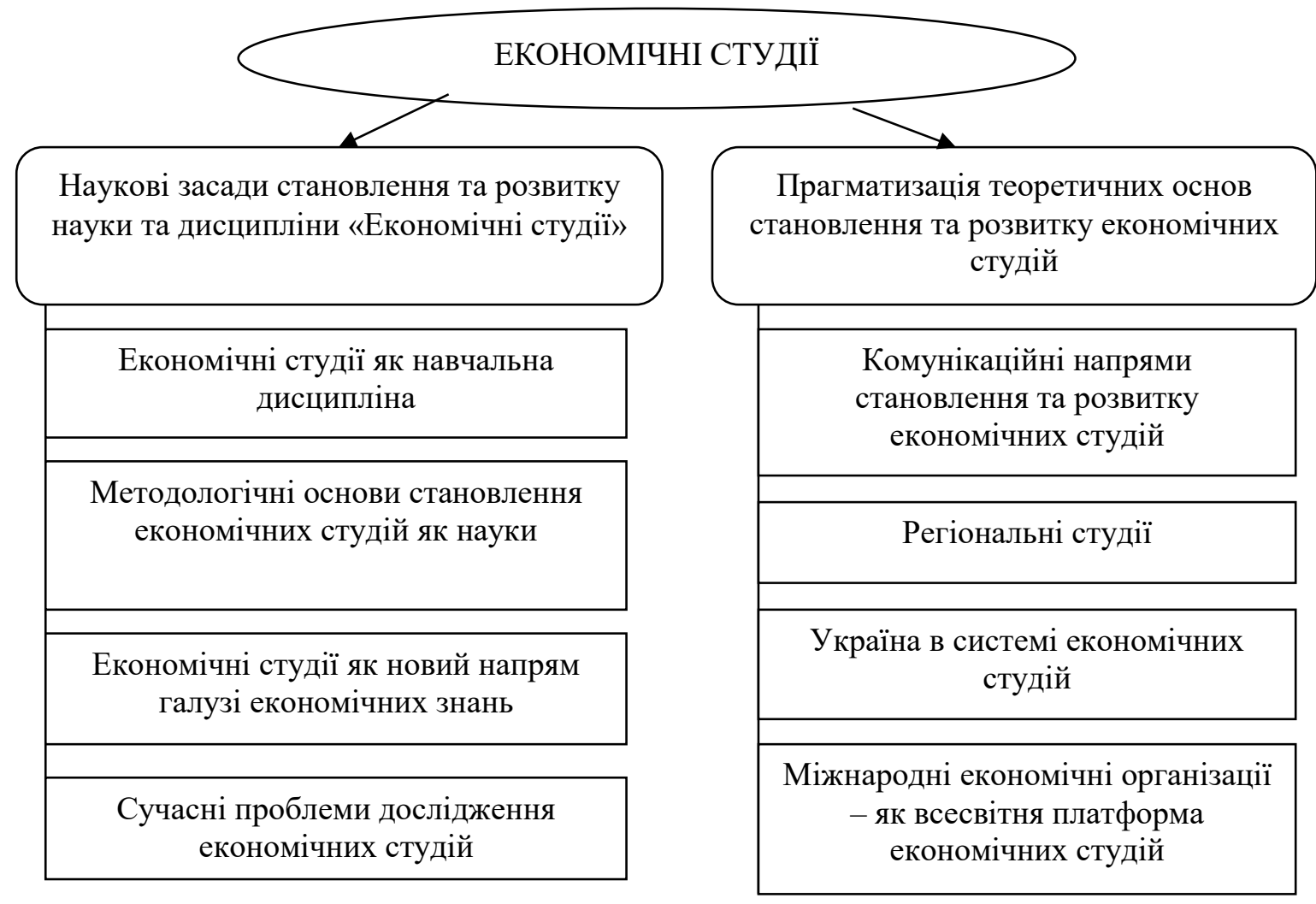

Рис. 2 Структура навчальної дисципліни «Економічні студії» Джерело: побудовано авторами

Економічні студії як навчальна дисципліна складається з двох компонентів:

1. Наукові засади становлення та розвитку науки та дисципліни «Економічні студії», тобто дослідження фундаментальних змін, які відбуваються у світі під впливом дії в економіці принципу технологічного детермінізму, що дає змогу проаналізувати динаміку розвитку економіки, а отже і суспільства в цілому, з точки зору минулого, реального теперішнього і передбаченого майбутнього [4]. Тобто підгрунтям цього компоненту є знання з економічної історії та економічної теорії щодо становлення та розвитку економічних відносин та економік взагалі.

2. Прагматизація теоретичних основ становлення та розвитку економічних студій. Питання, які повинні вирішуватися в повсякденному економічно-господарському житті, обумовлюють необхідність їх оперативного рішення за допомогою постійно діючого механізму. Таким механізмом виступають урядові, міжурядові організації, об'єднання виробників, наукових товариств, різноманітні системи комунікацій (наукові та науковопрактичні конференції, конгреси, семінари, проекти, програми тощо). В даному компоненті економічних студій актуальним $\epsilon$ включення питань, пов'язаних 3 дослідженнями національної економіки: iї ключових проблем та досягнень, міжнародному співробітництву та світовим рейтингам за певними показниками, що свідчать про економічний, інформаційний та технологічний розвиток країни. 
Особливу увагу слід приділити регіональним студіям - це комплексна категорія, якій відповідає дослідження та моніторинг процесів, що відбуваються в регіоні: історико-культурних, культурно-етичних, соціально-економічних, політичних, економіко-географічних, еколого-природничих та ін. [3].

Регіональні студії створюють аналітичну базу для прийняття рішень в сфері регіонального розвитку, навіть мають певну місцеву локацію. Одночасно, вони можуть створювати передумови для формування транснаціональних економічних і культурних зв'язків, що підтверджує тісний зв'язок регіональних з економічними студіями.

Висновки. Таким чином, у роботі визначені орієнтири дослідження дефініції «економічні студії», як поліконцептуальної системи знань та ії прагматизації в процесі вирішення соціально-економічних проблем. Також визначено місце економічних студій у сучасних наукових дослідженнях та зв'язок з багатьма навчальними дисциплінами: економічною теорією, міжнародними економічними відносинами, суспільними та маркетинговими комунікаціями; побудована структура економічних студій у контексті сучасної економічної теорії та практики господарювання.

Отже, всі поставлені у роботі завдання були вирішені. В подальших дослідженнях планується вивчення глобалістичної свідомості в понятті «економічні студії» в історикоекономічних та методологічних аспектах.

\section{Список бібліографічного опису:}

1. Економічна теорія: тенденції та розвиток системи економічних ідей : монографія / авт. кол.: Е. М. Забарна, Н. О. Задорожнюк, Н. І Волкова та [ін.] ; за заг. ред. Е. М. Забарної. Одеса, 2018. 392 с.

2. Парадигма інноваційного розвитку в умовах ринкової трансформації : монографія / Е. М. Забарна, О. М. Козакова, В. А. Чередниченко [та ін.] ; за заг. ред. Е. М. Забарної. Херсон, 2019. 92 с.

3. Забарна Е. М. ЕС та регіональні студії Одещини. Управління інноваційним розвитком на макро-, мезо- та мікрорівнях : матеріали IV Міжн. наук.-прак. Інтернет-конф. Одеса : ОНПУ, 7 червня 2018. С. 133-137.

4. Волкова Н. І., Задорожнюк Н. О. Економічні студії як новий напрям галузі економічних знань. Управління інноваційним розвитком на макро-, мезо- та мікрорівнях : матеріали V Міжн. наук.-прак. Інтернет-конф. Одеса : ОНПУ, 7-8 червня 2019. С. 26-28.

5. Івановський В. Що таке інформаційна інтервенція. Житомирінфо, 2015. URL: https://www.zhitomir.info/post_568.html (дата звернення: 13.02 .2020$)$.

6. Сториков Г. SMART-спеціалізація для стратегій регіонального розвитку в Україні URL: http://ufuti.pro/strategies/339smartspetsializatsiia-dlia-stratehii-rehionalnoho-rozvytku-v-ukraini.html(дата звернення: 13.02.2020).

\section{References:}

1. Zabarna, E. M. (2018). Ekonomichna teoriya: tendenciyi ta rozvy`tok sy`stemy` ekonomichny`x idej. [Economic theory: trends and development of the system of economic ideas]. Odesa : Astropry`nt. [in Ukrainian].

2. Zabarna, E. M. (2019). Parady`gma innovacijnogo rozvy`tku v umovax ry`nkovoyi transformaciyi. [The paradigm of innovative development in the conditions of market transformation]. Xerson : Oldi-plyus. [in Ukrainian].

3. Zabarna, E. M. (2018). ES ta regional'ni studiyi Odeshhy'ny'. [EU and regional studios of Odessa region], Materialy' IV Mizhn. nauk.prak. Internet-konf. «Upravlinnya innovacijny`m rozvy`tkom na makro-, mezo- ta mikrorivnyax», 133-137. [in Ukrainian].

4. Volkova, N. I., Zadorozhnyuk, N. O. (2019). Ekonomichni studiyi yak novy`j napryam galuzi ekonomichny’x znan'. [Economic studies as a new direction of the field of economic knowledge], Materialy` V Mizhn. nauk.-prak. Internet-konf. «Upravlinnya innovacijny`m rozvy`tkom na makro-, mezo- ta mikrorivnyax», 26-28. [in Ukrainian].

5. Ivanovs` ky`j, V. (2015). Sho take informacijna intervenciya. [What is an information intervention]. Zhy` tomy`rinfo - Zhytomyrinfo. URL: https://www.zhitomir.info/post_568.html. [in Ukrainian] (Last accessed: 13.02.2020).

6. Story kov, G. SMART-specializaciya dlya strategij regional’nogo rozvy`tku v Ukrayini. [SMART-specialization for regional development strategies in Ukraine]. URL: http://ufuti.pro/strategies/339-smartspetsializatsiia-dlia-stratehii-rehionalnoho-rozvytku-v-ukraini.html. [in Ukrainian] (Last accessed: 13.02.2020).

Дата подання публікації 17.03.2020 p. 